\title{
Seasonal variation, method of determination of bovine milk stability, and its relation with physical, chemical, and sanitary characteristics of raw milk
}

\author{
Sandro Charopen Machado ${ }^{1}$, Vivian Fischer ${ }^{\star}$, Marcelo Tempel Stumpf ${ }^{3}$, Sheila Cristina Bosco \\ Stivanin 4
}

\author{
${ }^{1}$ Faculdades de Itapiranga, Itapiranga, SC, Brazil. \\ 2 Universidade Federal do Rio Grande do Sul, Faculdade de Agronomia, Departamento de Zootecnia, Porto Alegre, RS, Brazil. \\ ${ }^{3}$ Universidade Federal do Rio Grande, Instituto de Ciências Biológicas, Lourenço do Sul, RS, Brazil. \\ ${ }^{4}$ Universidade Federal do Rio Grande do Sul, Programa de Pós-graduação em Zootecnia, Porto Alegre, RS, Brazil.
}

\begin{abstract}
The objective of this research was to determine the variation of milk stability evaluated with ethanol, boiling, and coagulation time tests (CTT) to identify milk components related with stability and verify the correlation between the three methods. Bulk raw milk was collected monthly at 50 dairy farms from January 2007 to October 2009 and physicochemical attributes, somatic cell (SCC), and total bacterial counts (TBC) were determined. Milk samples were classified into low, medium, and high stability to ethanol test when coagulation occurred at $72{ }^{\circ} \mathrm{GL}$, between 74 and $78^{\circ} \mathrm{GL}$, and above $78^{\circ} \mathrm{GL}$, respectively. Univariate analysis was performed considering the effects of year, months, and interaction in a completely randomized design. Principal factor analysis and logistic regression were done. There was an interaction between months and years for stability to the ethanol test and coagulation time. All samples were stable at the boiling test. Boiling test was not related to ethanol and coagulation time tests. Coagulation time was weakly but positively correlated with ethanol test. Broken line analysis revealed that milk stability measured with CTT and ethanol tests decreased sharply when SCC attained 790,000 or $106 \mathrm{cell} / \mathrm{mL}$ of milk, respectively. Milk stability measured with ethanol test decreased when TBC was higher than $250,000 \mathrm{cfu} / \mathrm{mL}$, while there was no inflexion point between TBC and stability measured with CTT. Milk with high stability presented lower values for acidity, TBC, and SCC but higher values for $\mathrm{pH}$, lactose, protein, and CTT compared with lowstability milk. Due to the execution easiness, single-point cut-off result and low cost, we do not recommend the replacement of ethanol test for boiling or coagulation time test.
\end{abstract}

Key Words: milk composition, seasonality, somatic cell count

\section{Introduction}

Stability of milk is a multifactorial phenomenon, which can be influenced by milk acidity, $\mathrm{pH}$, composition of casein micelles, ionic calcium concentration, among others (Lewis and Deeth, 2009; Fischer et al., 2012; Horne, 2015). Milk stability has been accessed by tests, such as ethanol, boiling, sedimentation and viscosity, and coagulation time. In Brazil, milk stability is estimated by the ethanol test performed at the farm and dairy plant platform (Brasil, 2011).

Received: July 5, 2016

Accepted: November 21, 2016

*Corresponding author: vivinha.fischer@hotmail.com

http://dx.doi.org/10.1590/S1806-92902017000400010

How to cite: Machado, S. C.; Fischer, V.; Stumpf, M. T. and Stivanin, S. C. B. 2017. Seasonal variation, method of determination of bovine milk stability, and its relation with physical, chemical, and sanitary characteristics of raw milk. Revista Brasileira de Zootecnia 46(4):340-347.

Copyright (C) 2017 Sociedade Brasileira de Zootecnia. This is an Open Access article distributed under the terms of the Creative Commons Attribution License (http://creativecommons.org/licenses/by/4.0/), which permits unrestricted use, distribution, and reproduction in any medium, provided the original work is properly cited.
Milk with low stability to ethanol test (coagulation at $72{ }^{\circ} \mathrm{GL}$ ) is considered unsuitable for industrial procedures involving heating and should not be transported to the industry (Brasil, 2011). Although usage of single-point ethanol test for grading milk to thermal process is not used in western developed countries, it is still used in Latin America, Africa, and Far East (Lin et al., 2009; Kassa et al., 2013; Horne, 2015; Rathnayake et al., 2016). The main reason is because it represents a simple, rapid, practical, and low-cost test in regions characterized by large number of dairy farms and low technology, rendering other more sophisticated methods impractical (Horne, 2015).

Discussion about the suitability of indirect test to estimate milk stability still persists. Previous studies have shown that milk ethanol stability is weakly related to coagulation time test (CTT) (Molina et al., 2001) and milk traits associated to them are quite different (Chavez et al., 2004). Milk ethanol stability is related to the ionic strength, potassium, and chloride contents while coagulation time is related to $\mathrm{pH}$, urea, and phosphorus contents. Both tests are related to ionic calcium (Negri et al., 2001). These authors 
collected milk samples in autumn and spring and only considered milk with less than $100.000 \mathrm{cfu} / \mathrm{mL}$.

It might be worth evaluating how milk stability varies during the whole year and how milk stability varies when milk with wider range of sanitary and hygienic-related traits is considered, even more considering the high values of somatic cell count and total bacterial count in milk produced in Brazil and other developing countries. Therefore, it may be worth studying how milk stability changes between and within years, if this variability is related to other milk traits, and how the ethanol test correlates with coagulation time and boiling tests. The study was carried out to determine the seasonal variation of milk stability evaluated with ethanol, boiling, and coagulation time tests, identify milk components related with the results, and verify the correlation among the three methods.

\section{Material and Methods}

The experiment was conducted between January 2007 and October 2009 in the northeast region of Rio Grande do Sul, Brazil. Raw bulk milk samples from 50 dairy farms were evaluated once a month, totaling 1700 milk samples. All producers sold their milk to a local industry and were randomly selected within all milk production extracts. Approximately, a volume of $200 \mathrm{~mL}$ of raw milk was collected from cooling bulk tanks at each milk supplier into 250-mL milk sampling bottles, and immediately transferred to the laboratory under cooling conditions for further analysis. Milk samples were divided into two aliquots. The first one was used to determine total bacterial count (TBC) and somatic cell count (SCC) by flow cytometry and milk chemical composition (lactose, protein, fat, and total solids) by infrared radiation spectrophotometry (Fonseca and Santos, 2000). The second aliquot was analyzed for: a) titratable acidity and $\mathrm{pH}$ by potenciometry; b) boiling test: $3 \mathrm{~mL}$ of milk was placed into a test tube and heated until the boiling point, for three times for each sample, followed by the visual inspection of clot formation. Clot formation was considered as a positive result in the test, otherwise the result would be considered negative; c) stability to the ethanol test: equal amounts of milk and solution with ethanol concentration varying from 68 to $80^{\circ} \mathrm{GL}$ were mixed in a Petri dish until visual clot detection. Milk stability was settled as the minimal ethanol concentration, which induced clot formation. Milk samples with absence of clot formation when mixed with solution with $80^{\circ} \mathrm{GL}$ ethanol were considered unstable at $81{ }^{\circ} \mathrm{GL}$; and d) coagulation time test, executed between November 2008 and October 2009. Each milk sample was inserted into an individual glass capillary with $120 \mathrm{~mm}$ of length, $0.15 \mathrm{~mm}$ of external diameter, and $0.08 \mathrm{~mm}$ of internal diameter. Both ends of the capillary were closed. After that, the capillary was immersed in glycerin at $145^{\circ} \mathrm{C}$; the coagulation time was the time elapsed between the immersion and the visualization of clots inside the capillary (Negri et al., 2001).

Farms were considered as experimental units. Data about ethanol test were analyzed according to a completely randomized design in a factorial arrangement (months and years) with repeated measurements, using the SAS software (Statistical Analysis System, version 9.3) and applying the procedure PROC MIXED (ANOVA), considering the effects of months and tests of means (LSmeans) for significant variables. P-values $(<0.05)$ were considered significant. Year and months were considered as fixed effects, while farms were the random term and months the repeated measurements.

The statistical model used was:

$$
\mathrm{Y}_{\mathrm{ijk}}=\mu+\alpha_{\mathrm{i}}+\beta_{\mathrm{j}}+(\alpha \times \beta)_{\mathrm{ij}}+\mathrm{f}_{\mathrm{k}}+\mathrm{e}_{\mathrm{ijk}} \text {, }
$$

in which $Y_{\mathrm{ijk}}$ is observation made for each farm $k$ on each month $i$ on year $j ; \mu$ is overall mean; $\alpha_{i}$ is the effect of the months $\mathrm{i} ; \beta_{\mathrm{j}}$ is the effect of the year $\mathrm{j} ;(\alpha \times \beta)_{\mathrm{ij}}$ is the effect of the interaction between years and months; $f_{k}$ is the random effect of farm $\mathrm{k}$; and $\mathrm{e}_{\mathrm{ijk}}$ is random error associated with each observation.

Because of missing data, analysis for CTT was performed just considering the year of 2009 and the effect of months.

The statistical model used was:

$$
\mathrm{Y}_{\mathrm{ij}}=\mu+\alpha_{\mathrm{i}}+\mathrm{f}_{\mathrm{j}}+\mathrm{e}_{\mathrm{ij}}
$$

in which $Y_{i j}$ is observation made for each farm $j$ on each month $\mathrm{i} ; \mu$ is the overall mean; $\alpha_{\mathrm{i}}$ is the fixed effect of the months $\mathrm{i} ; \mathrm{f}_{\mathrm{j}}$ is the random effect of farm; and $\mathrm{e}_{\mathrm{ij}}$ is random error associated with each observation.

The boiling test values were registered as a binomial variable (presence or absence of coagulated milk) and further analyzed using NPAR1WAY procedure of SAS. Values of SCC and TBC were converted using logarithmic transformation $\left(\log _{10}\right)$ to homogenate variance and fit normal distribution.

Complementarily descriptive analysis was done using UNIVARIATE and FREQ procedures of SAS to calculate mean, mode, median, maximal, and minimal values. Correlation among methods of stability determination was performed using PROC CORR (coefficient of Spearman) of SAS.

The principal factor analysis (PROC FACTOR) was performed with seven milk traits and the msa option to measure the adequacy of the traits was used in the statistical procedure to select the variables.

Logistic and broken line regressions were calculated to determine the limiting ethanol concentrations used to 
test milk stability, in which inflexion in the milk traits such as $\mathrm{pH}$, TBC, and SCC occurred. Logistic and broken line regressions were performed using NLIN and LOGISTIC procedures of SAS, respectively.

The model used for the broken regression line was:

$$
\mathrm{Y}_{\mathrm{i}}=\beta_{0}+\beta_{1} \mathrm{x}_{\mathrm{i} 1}+\beta_{2}\left(\mathrm{x}_{\mathrm{i} 1}-\mathrm{x}\right) \delta_{\mathrm{i}}+\varepsilon_{\mathrm{i}},
$$

in which $\delta_{\mathrm{i}}=1$, if $\mathrm{x}_{\mathrm{i} 1}>\mathrm{x}$ and 0 , if $\mathrm{x}_{\mathrm{i} 1}<\mathrm{x} ; \mathrm{y}_{\mathrm{i}}$ is ethanol stability; $\mathrm{x}$ is a milk trait such as $\mathrm{pH}, \mathrm{TBC}$, or $\mathrm{SCC}$; and $\beta$ is the regression coefficient.

The model used for the logistic regression was:

$$
\operatorname{logit}(\mathrm{p})=\beta_{0}+\beta_{1} \mathrm{x}_{\mathrm{i} 1},
$$

in which (p) is the probability of occurrence of unstable milk (LINA); $\mathrm{x}$ is the independent variable; and $\beta$ is the regression coefficient. Milk was considered unstable when it precipitated in solution with $72{ }^{\circ} \mathrm{GL}$ or less.

To access the differences of composition between milk samples with distinct stability, milk samples were classified into low, medium, and high stability to ethanol test when coagulation occurred at 72 or less than $72^{\circ} \mathrm{GL}$, between 74 and $78^{\circ} \mathrm{GL}$, and above $78^{\circ} \mathrm{GL}$, respectively. Milk attributes were subjected to analysis of variance according to stability classification using GLM procedure of SAS and tests of means (LSmeans) for significant variables. P-values were considered significant at $<0.05$.

The statistical model used was:

$$
Y_{i}=\mu+\alpha_{i}+e_{i}
$$

in which $\mathrm{Y}_{\mathrm{i}}$ is observation made for each stability $i ; \mu$ is the overall mean; $\alpha_{i}$ is the effect of the stability class; and $e_{i}$ is the experimental error.

\section{Results}

Descriptive statistics of the raw data revealed that, from the 50 dairy farms, $78.4 \%$ of the farmers had low level of formal education as they studied until the eighth school grade, $72 \%$ of the farms allocated less than 15 ha to the dairy activity, and all herds were composed by predominantly Holstein breed. Milking was done manually in $25 \%$ of the farms. Most of the farmers (91.3\%) executed both milking and feeding practices. Feeding practices were diversified, but it could be noticed that in $97 \%$ of the farms, corn silage was used, $82 \%$ of the farmers used commercial concentrate sold by the dairy industry with 20 to $22 \%$ crude protein, $68 \%$ of the farms cultivated warm (pearl millet) and cold season pastures (black oats), but only 5\% used hay. Practices for prevention against mastitis, such as pre- dipping and post-dipping were adopted by 12 and $74 \%$ of the farmers, respectively, while clinical (stripping milk into a strip cup) and subclinical mastitis tests were adopted by $45 \%$ of farmers. Milk was cooled in bulk tanks in all farms evaluated.

Overall milk stability to the ethanol test was $74.8^{\circ} \mathrm{GL}$ (Tables 1 and 2). However, approximately $35 \%$ of milk samples were unstable in $72{ }^{\circ} \mathrm{GL}$ ethanol and $81 \%$ were unstable in $78^{\circ} \mathrm{GL}$ ethanol. Milk stability to ethanol test varied among months within the years 2007 and 2009 $(\mathrm{P}<0.05)$, but did not significantly vary in 2008. In 2007, minimal values were registered in January $\left(73.86{ }^{\circ} \mathrm{GL}\right)$, February $\left(74.06^{\circ} \mathrm{GL}\right)$, April $\left(74.84^{\circ} \mathrm{GL}\right)$, and November $\left(74.02{ }^{\circ} \mathrm{GL}\right)$, while maximal values were found in August (78.12 $\left.{ }^{\circ} \mathrm{GL}\right)$, July $\left(76.76^{\circ} \mathrm{GL}\right)$, and September $\left(76.08^{\circ} \mathrm{GL}\right)$. In 2009, minimal values were registered in January $\left(73.53{ }^{\circ} \mathrm{GL}\right)$ and February $\left(73.47^{\circ} \mathrm{GL}\right)$, while maximal values were observed in July $\left(76.15^{\circ} \mathrm{GL}\right)$, August $\left(76.13^{\circ} \mathrm{GL}\right)$, and September $\left(76.31^{\circ} \mathrm{GL}\right)$.

All samples were stable in the boiling test regardless of year and months within year of evaluation. Overall mean for milk CTT was 5 min but it varied from 0.2 to 30.0 minutes (Table 1).

Stability of milk to the ethanol test was moderately and positively correlated with CTT $(r=0.28, \mathrm{P}<0.0001$,

\begin{tabular}{|c|c|c|c|c|c|c|}
\hline Attribute & $\mathrm{n}$ & Mean & Median & Mode & Amplitude & $\mathrm{CV}(\%)$ \\
\hline $\mathrm{pH}$ & 1583 & 6.8 & 6.8 & 6.8 & $6.3-7.0$ & 1.2 \\
\hline Titratable acidity $\left({ }^{\circ} \mathrm{D}\right)$ & 1583 & 15.9 & 16.0 & 15.0 & $13-19$ & 8.6 \\
\hline Ethanol $\left({ }^{\circ} \mathrm{GL}\right)$ & 1700 & 74.8 & 76.0 & 78.0 & $68-81$ & 5.6 \\
\hline CTT (min) & 588 & 5.04 & 4.42 & 3.45 & $0.2-30.0$ & 56.2 \\
\hline Boiling test ${ }^{1}$ & 1700 & 0 & 0 & 0 & 0 & 0 \\
\hline $\log _{10}(\mathrm{TBC})^{2}$ & 1569 & 6.0 & 6.0 & 5.5 & $4.4-7.2$ & 10.0 \\
\hline $\log _{10}(\mathrm{SCC})^{2}$ & 1583 & 5.8 & 5.8 & 5.7 & $4.5-6.6$ & 5.6 \\
\hline Lactose (g/kg) & 1583 & 44.5 & 43.8 & 44.5 & $32.0-48.0$ & 4.2 \\
\hline Protein $(\mathrm{g} / \mathrm{kg})$ & 1583 & 31.0 & 30.9 & 30.1 & $21.0-39.0$ & 6.2 \\
\hline Fat $(\mathrm{g} / \mathrm{kg})$ & 1583 & 38.5 & 37.4 & 37.8 & $21.0-57.0$ & 23.2 \\
\hline
\end{tabular}

Table 1 - Descriptive analysis of the physical-chemical and sanitary attributes of milk produced by 50 farmers in the northeast region of Rio Grande do Sul from 2007 to 2009

CTT - coagulation time test; TBC - total bacterial count; SCC - somatic cell count; CV - coefficient of variation.

${ }^{1}$ Boiling test: frequency of precipitation following boiling.

${ }^{2}$ Values of total bacterial count and somatic cell count following $\log _{10}$ transformation. 
$\mathrm{n}=588), \mathrm{pH}(\mathrm{r}=0.28, \mathrm{P}<0.0001, \mathrm{n}=1700)$, lactose $(\mathrm{r}=0.31$, $\mathrm{P}<0.0001, \mathrm{n}=1621)$, and protein $(\mathrm{r}=0.1, \mathrm{P}<0.0001, \mathrm{n}=1621)$, but moderately and negatively correlated with titratable acidity $(\mathrm{r}=-0.22, \mathrm{P}<0.0001, \mathrm{n}=1700)$ and $\log _{10} \mathrm{TBC}$ $(\mathrm{r}=-0.20, \mathrm{P}<0.0001, \mathrm{n}=1615)$ and weakly related with $\log _{10} \mathrm{SCC}(\mathrm{r}=-0.07, \mathrm{P}=0.0069, \mathrm{n}=1621)$. Coagulation time test was positively related with $\mathrm{pH}(\mathrm{r}=0.20, \mathrm{P}<0.0001, \mathrm{n}=$ $591)$ and lactose $(\mathrm{r}=0.2, \mathrm{P}<0.0001, \mathrm{n}=591)$, but negatively correlated with titratable acidity $(\mathrm{r}=-0.17, \mathrm{P}<0.0001, \mathrm{n}=$ 591), $\log _{10} \mathrm{TBC}(\mathrm{r}=-0.15, \mathrm{P}<0.0003, \mathrm{n}=591)$, and $\log _{10} \mathrm{SCC}$ $(\mathrm{r}=-0.13, \mathrm{P}=0.0019, \mathrm{n}=591)$.

Principal factor analysis confirmed previous correlations mentioned before, as it highlighted a positive association between stability measured with ethanol test, CTT, pH, and concentration of lactose and a negative association of milk stability (ethanol and CTT) with acidity and TBC (Figure 1).

Broken line analysis revealed that milk stability values measured with CTT and ethanol test decreased sharply when SCC values attained 790,000 or $1,000,000$ cell $/ \mathrm{mL}$ of milk, respectively. Besides, milk stability measured with ethanol test decreased when TBC was higher than $250,000 \mathrm{cfu} / \mathrm{mL}$, while there was no inflexion point between TBC and stability measured with CTT. In addition, inflexion points for milk stability measured with CTT and ethanol test were observed at $\mathrm{pH}$ value of 6.65 , decreasing with lower $\mathrm{pH}$ values. There was not an

Table 2 - Frequency of occurrence of values within and out the range accepted by the normative instruction 62 for the physical-chemical and sanitary characteristics of milk produced by 50 farmers in the northeast region of Rio Grande do Sul from 2007 to 2009

\begin{tabular}{lccc}
\hline \multirow{2}{*}{ Attribute } & \multicolumn{3}{c}{ Frequency of samples in each range $(\%)$} \\
\cline { 2 - 4 } & $<6.6$ & $6.6-6.8$ & $>6.8$ \\
\hline $\mathrm{pH}^{1}$ & 0.4 & $6.6-6.8$ & $>6.8$ \\
& $<14$ & 91.7 & 7.8 \\
Titratable acidity $\left({ }^{\circ} \mathrm{D}\right)^{1}$ & 0.1 & $14-18$ & $>18$ \\
& $\leq 72$ & 99.8 & 0.1 \\
Stability to alcohol test $\left({ }^{\circ} \mathrm{GL}\right)^{1}$ & 35.2 & $73-78$ & $>78$ \\
& $\leq 200,000$ & $200,000-600,000$ & $>600,000$ \\
TBC $\left(\mathrm{cfu} / \mathrm{mL} \times 10^{3}\right)^{1}$ & 5.8 & 32.1 & 37.9 \\
SCC $\left(\mathrm{SC} / \mathrm{mL} \times 10^{3}\right)^{1}$ & $\leq 100,000$ & $100,000-600,000$ & $>600,000$ \\
Lactose $(\mathrm{g} / 100 \mathrm{~g})^{1}$ & 8.3 & 40.1 & 51.6 \\
& $<4.3$ & - & $\geq 4.3$ \\
Protein $(\mathrm{g} / 100 \mathrm{~g})^{1}$ & 30.1 & - & 699 \\
Fat $(\mathrm{g} / 100 \mathrm{~g})^{1}$ & $<2.9$ & - & $\geq 2.9$ \\
& 9.9 & - & 90.1 \\
& 2.1 & - & 93.0 \\
\hline
\end{tabular}

TBC - total bacterial count; SCC - somatic cell count.

${ }^{1}$ Reference value according to normative instruction 62, IN62 (Brasil, 2011). inflexion point between CTT and ethanol test, which was confirmed by the linear relation between the two methods of predicting milk stability $\left(\mathrm{CTT}=0.12 \mathrm{x}-4.1, \mathrm{R}^{2}=0.05\right.$, $\mathrm{X}=$ concentration of ethanol, $\left.{ }^{\circ} \mathrm{GL} ; \mathrm{P}<0.0001\right)$.

Logistic analysis showed that an increase in each unit of $\log _{10}$ TBC or $\log _{10}$ SCC increased the odds of occurrence of unstable milk by 2.23 and 1.6 times, respectively $(\mathrm{P}<0.01)$. The increase in each minute of CTT test increased the odds of occurrence of ethanol stable milk by 1.15 times $(\mathrm{P}<0.01)$.

Milk with higher stability in the ethanol test (coagulated at ethanol above $78^{\circ} \mathrm{GL}$ ) presented lower values for acidity, $\mathrm{TBC}$, and $\mathrm{SCC}$ but higher $\mathrm{pH}$, levels of lactose, and protein and lasted longer in the CTT without the formation of clots when compared with unstable milk samples (coagulated when mixed with ethanol at $72{ }^{\circ} \mathrm{GL}$ or less), which makes it more suitable for dairy industry (Table 3 ).

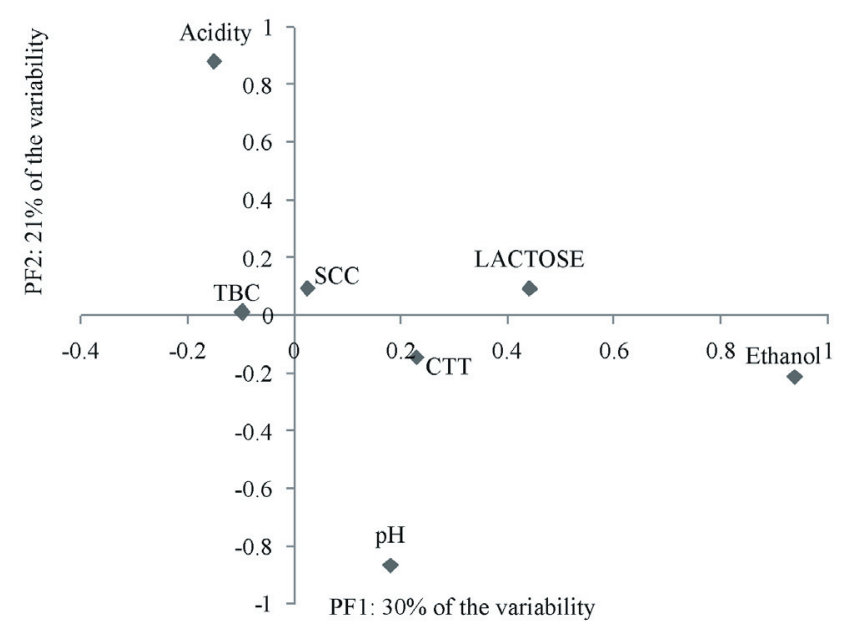

PF - principal factor analysis; TBC - total bacterial count; SCC - somatic cell count; CTT - coagulation time test.

Figure 1 - Orthogonal plan with principal factors for milk components and stability tests.

Table 3 - Mean values for attributes in raw milk samples from 50 dairy farms presenting high $\left(>78^{\circ} \mathrm{GL}\right)$, intermediary (from 72 to $78^{\circ} \mathrm{GL}$ ), or low $\left(\leq 72{ }^{\circ} \mathrm{GL}\right)$ stability to the ethanol test with corresponding significance levels

\begin{tabular}{lccccc}
\hline \multirow{2}{*}{ Attribute } & \multicolumn{3}{c}{ Ethanol stability } & \multirow{2}{*}{$\mathrm{P}>\mathrm{F}$} & $\mathrm{CV}(\%)$ \\
\cline { 2 - 4 } & $\leq 72^{\circ} \mathrm{GL}$ & $72>\mathrm{X} \leq 78^{\circ} \mathrm{GL}$ & $>78^{\circ} \mathrm{GL}$ & & \\
\hline $\mathrm{pH}$ & $6.7 \mathrm{a}$ & $6.8 \mathrm{~b}$ & $6.8 \mathrm{~b}$ & $<0.0001$ & 1.2 \\
Acidity $\left({ }^{\circ} \mathrm{D}\right)$ & $16.2 \mathrm{a}$ & $15.7 \mathrm{~b}$ & $15.5 \mathrm{c}$ & $<0.0001$ & 8.4 \\
Lactose $(\mathrm{g} / 100 \mathrm{~g})$ & $4.3 \mathrm{a}$ & $4.4 \mathrm{~b}$ & $4.4 \mathrm{c}$ & $<0.0001$ & 3.6 \\
Protein $(\mathrm{g} / 100 \mathrm{~g})$ & $3.08 \mathrm{a}$ & $3.12 \mathrm{~b}$ & $3.11 \mathrm{~b}$ & 0.0043 & 5.9 \\
Fat $(\mathrm{g} / 100 \mathrm{~g})$ & 3.7 & 3.8 & 3.8 & 0.1171 & 10.2 \\
$\mathrm{CTT}($ minutes $)$ & $4.5 \mathrm{a}$ & $5.2 \mathrm{~b}$ & $5.6 \mathrm{~b}$ & $<0.0001$ & 49.1 \\
$\log _{10}$ (SCC) & $5.8 \mathrm{a}$ & $5.8 \mathrm{~b}$ & $5.8 \mathrm{~b}$ & 0.0159 & 5.5 \\
$\log _{10}$ (TBC) & $6.1 \mathrm{a}$ & $5.9 \mathrm{~b}$ & $5.9 \mathrm{~b}$ & $<0.0001$ & 9.8
\end{tabular}

CTT - coagulation time test; SCC - somatic cell count; TBC - total bacterial count; $\mathrm{CV}$ - coefficient of variation.

a,b,c - means in the same row followed by different letters are significantly different (lsmeans; $\mathrm{P}<0.05$ ). 


\section{Discussion}

Milk stability is a complex issue (Horne, 2015) and some milk characteristics have been consistently related to low ethanol stability, such as acidity (Rathnayake et al., 2016) ionic calcium concentration (Tsioulpas et al., 2007; Lewis, 2011; Nian et al., 2012), ionic strength (Chavez et al., 2004), phosphate (Gaucheron, 2005), and citrate contents (Tsioulpas et al., 2007). Other milk characteristics were not consistently related to stability. Some studies have reported significant effects on stability related to the casein composition (Barbosa et al., 2012), while other have not reported significant effects (Marques et al., 2011; Botaro et al., 2007, 2009). Somatic cell count (SCC) has been controversially related to low stability, as some studies reported a relation between high SCC and low stability (Oliveira et al., 2011; 2013), while others have shown no relation (Kolling, 2012).

Factors related to the animals, such as extended lactation period (Marques et al., 2010a; Tsioulpas et al., 2007), affect milk stability. Feed restriction (Gabbi et al., 2013, 2016), excess of fiber in the diet (Barchiesi-Ferrari et al., 2007), or nutrient imbalance (Marques et al., 2010b) negatively affect milk stability, although the underlying mechanisms are not completely determined; however, it seems that metabolism disturbance leading to metabolic acidosis (Fagnani et al., 2014; Marques et al., 2011) and higher permeability of the tight junctions of epithelial mammary cells (Stumpf et al., 2013) is probably enrolled as a causal factor of the low milk stability.

The present study aimed to highlight the suitability of indirect test to estimate milk stability and identify the milk traits related to milk stability. We might consider some limitations of our study. We monitored only 50 dairy farms and, although they were representative of the range of farms of this region concerning milk production, feeding, and milking practices, they might be not representative of dairy farms located in other regions. On the other hand, as these farms were monthly monitored for 36 months, a considerable number of milk samples were collected and analyzed, giving robustness to the results about the effect of seasonality and correlation between methods. The farm characteristics were surveyed twice a year but they were not taken into consideration in the multivariate analysis. We are also aware that the mineral components such as ionic calcium, ionic magnesium, chlorides, potassium, sodium, citrate, phosphate, and ionic strength were not measured. These measurements are expensive and laborious and are not usually performed by dairy industries. Extrapolations of the results and considerations and inferences should be made with caution and with these limitations in mind.

Overall ethanol stability value $\left(74.8^{\circ} \mathrm{GL}\right)$ was higher than $72{ }^{\circ} \mathrm{GL}$, which is the minimal threshold required by the IN62 for raw milk (Brasil, 2011), and approached the value indicated for UHT process (Farahnik, 1982). High occurrence of milk ethanol instability, not related to excessive acidity, was previously reported in other regions by Marques et al. (2007) in Rio Grande do Sul, Brazil; Oliveira et al. (2011) in São Paulo, Brazil; Fagnani et al. (2016) in Paraná, Brazil; and Lin et al. (2009) in the eastern Taiwan.

Low and high ethanol stability values observed in different months, depending on the year, might be partially explained by variation in feed supply or feed quality with consequent changes in mineral composition (Tsioulpas et al., 2007; Lewis 2011; Stumpf et al., 2013; Horne, 2015). The overall low stability value observed in 2008 was probably related to the occurrence of the La Niña phenomenon, which led to shortages in rainfall, mostly on spring and summer, reducing the production and quality of feeds offered to the animals. In 2007 and 2009, high values for milk stability were observed when cool season pastures were actively growing (July to October) and when silage was supplied to the animals (March to June); low stability was registered in the beginning of summer, when the land is used for corn cultivation, and in the beginning of autumn, when a forage gap is very frequent.

The absence of coagulation in the boiling test might be due to the fact that no sample presented $\mathrm{pH}$ below 6.5 or acidity above $20^{\circ} \mathrm{D}$ and confirmed its low sensitivity compared with ethanol test, as previously reported by Fonteh et al. (2005) and Silva et al. (2012).

The huge variation observed for CTT was already noticed (Chavez et al., 2004), but one of the limitations of this test is the lack of a clear definition of the value for the low threshold for milk stability (Molina et al., 2001); therefore, its comparison with the ethanol test remains inconclusive (Negri et al., 2001). It is only possible to assume that, the longer milk resists to the treatment without the formation of clots, the greater is its thermal stability, but there are doubts about the reliability of this test to estimate thermal stability at the dairy industry (Lewis and Deeth, 2009; Horne, 2015). Values of coagulation time test were lower than those previously reported by Molina et al. (2001) and Chavez et al. (2004), who observed the formation of clots between 10 and $20 \mathrm{~min}$ and after $20 \mathrm{~min}$ in immersion, respectively. This fact might partially be related to the saline imbalance, as $51.6 \%$ of the samples of the present study presented SCC higher than 600,000 
cells/mL, in contrast with Chavez et al. (2004), who did not analyze milk with more than 500,000 cells $/ \mathrm{mL}$. As we used the same kind of oil bath and glass capillaries described by Negri et al. (2001) and Chavez et al. (2004), differences concerning personal and laboratory facilities should have been of minor importance.

The positive, although moderate, correlation between CTT and ethanol test observed in the present study (linear correlation and principal factor analysis) has already been reported (Molina et al., 2001; Chavez et al., 2004) and might be due to the different challenges they impose to milk components, i.e. dehydration and increase of the dielectric constant promoted by ethanol test and heating by CTT. Although the relation was positive and significant, the coefficient of determination was very low, as already noticed (Singh, 2004). To the knowledge of the authors, despite the results of Negri et al. (2011), there is no advantage to choose CTT instead of ethanol stability test to estimate milk stability (Horne, 2015).

Milk stability is negatively related to acidity, because the reduction in $\mathrm{pH}$ reduces calcium phosphate caseinate and enhances ionic calcium concentration, which in turn decreases repulsion forces among caseins, favoring coagulation (Lewis, 2011; Horne, 2015). Horne and Muir (1990), Chavez et al. (2004), and Lewis (2011) reported that results in the ethanol test and CTT were adversely affected by ionic calcium concentration. The output of calcium phosphate from the micellar structure leads to the exposition of the hydrophobic portion of the caseins, enhancing the propensity for aggregation (Philippe et al. 2003).

In the present study, $47.3 \%$ and $52.3 \%$ of samples presented $\mathrm{pH}$ between 6.5 and 6.7 and between 6.7 and 7.0 , respectively. These variations, although minimal, can affect the stability of milk. Within the range of 6.5 to 6.7, as $\mathrm{pH}$ increases, the concentration of ionic calcium reduces and stability of casein micelles is enhanced. Between 6.7 and 7.0, the $\kappa$-caseins separate from the micelles, reducing the stability of milk. Above 7.0, the concentration of ionic calcium is lowered and the stability increases (Horne and Muir, 1990; Singh, 2004; Horne, 2015).

The negative association between SCC and milk stability observed in the correlation analysis, but not in the principal factor analysis, was also found by Marques et al. (2010a,b) and Oliveira et al. $(2011 ; 2013)$. In the present study, the sanitary quality of milk was low, as $51.7 \%$ of samples presented SCC levels above 600,000 cells $/ \mathrm{mL}$. High values for SCC are probably related to low milk stability due to proteolysis, low casein contents, high values of sodium and chlorine contents, and micelle destabilization (Chavez et al., 2004; Horne, 2015); on the other hand, high values for $\mathrm{TBC}$ are related to low milk stability, probably due to proteolysis and lactose degradation, which leads to lower $\mathrm{pH}$ and calcium phosphate values and further increase in ionic calcium concentrations and micelle destabilization (Auldist and Hubble, 1998; Chavez et al., 2004; Bueno et al., 2008; Lewis and Deeth, 2009). The increase in the paracellular flow of components between the blood stream and the milk when SCC is elevated (Stelwagen et al., 2000) leads to elevated levels of sodium, chloride, and phosphorus in milk (Smyth et al., 2004) and might be related to low stability. However, Donatele et al. (2003) and Kolling (2012) found no relationship between TBC, SCC, and milk stability.

These relations between milk stability and milk traits are supported by differences in composition presented by milk with low, medium, and high ethanol stability. Differences in lactose and protein contents between milk with high stability and unstable milk are partially due to inadequate supply of nutrients, feeding of low-quality forages, metabolic or ruminal disturbances, and poor hygienic-sanitary characteristics of milk (Zanela et al., 2006; Barchiesi-Ferrrari et al., 2007; Marques et al., 2010a; Fagnani et al., 2014; Gabbi et al., 2016; Werncke et al., 2016).

Until now, factors that can be used to predict the behavior of raw milk in stability tests and in industrial procedures involving heating have not been completely identified (Horne, 2015). Lewis (2011) suggested that levels of ionic calcium are involved and recommended its measurement. However, it requires expensive ion-selective electrodes and demands training of personal engaged in routine tests at the industry. The absence of a defined minimal threshold for coagulation time, besides the time spent in its application (that can last for few seconds until several minutes) and personal health issues (smoke produced by glycerin heating) impair the implementation of CTT in the industry or on the farm as a routine test of milk stability. Boiling test presents some favorable aspects such as easiness, clear cut-off point, and low cost, but is much less sensitive and predictive than CTT and ethanol test to evaluate milk stability, as it did not vary in the present study despite huge changes in milk composition.

\section{Conclusions}

Stability varies among years and months within year and according to the method used. Milk is stable in the boiling test. Indirect methods of milk stability evaluation are poorly correlated. High ethanol stability milk presents better chemical composition than low stability milk. Among the indirect methods for estimating milk stability, ethanol test remains as the most suitable. 


\section{Acknowledgments}

Authors acknowledge the technical staff of Piá Cooperativa Agropecuária Petrópolis Ltda. - for technical support in collecting milk samples and some laboratory analysis, and Conselho Nacional de Desenvolvimento Científico e Tecnológico - CNPq for the financial support (476556/2008-2).

\section{References}

Auldist, M. J. and Hubble, I. B. 1998. Effects of mastitis on raw milk and dairy products. Australian Journal of Dairy Technology 53:28-36

Barbosa, R. S.; Fischer, V.; Ribeiro, M. E. R.; Zanela, M. B.; Stumpf, M. T.; Kolling, G. J.; Schafhäuser Júnior, J.; Barros, L. E. and Egito, A. S. 2012. Caracterização eletroforética de proteínas e estabilidade do leite em vacas submetidas à restrição alimentar. Pesquisa Agropecuária Brasileira 47:621-628.

Barchiesi-Ferrari, C. G.; Williams-Salina, P. A. and Salvo-Garrido, S. I. 2007. Inestabilidad de la leche asociada a componentes lácteos y estacionalidad en vacas a pastoreo. Pesquisa Agropecuária Brasileira 42:1785-1791.

Botaro, B. G.; Lima, Y. V. R.; Aquino, A. A.; Fernandes, R. H. R.; Garcia, J. F. and Santos, M. V. 2007. Beta-lactoglobulin polymorphism does not affect physicochemical characteristics and milk stability. Pesquisa Agropecuária Brasileira 42:747-753

Botaro, B. G.; Lima, Y. V. R.; Cortinhas, C. S.; Silva, L. F. P.; Rennó, F. P. and Santos, M. V. 2009. Effect of the kappa-casein gene polymorphism, breed and seasonality on physicochemical characteristics, composition and stability of bovine milk. Revista Brasileira de Zootecnia 38:2447-2454.

Brasil. 2011. Instrução Normativa n. 62, de 29 de dezembro de 2011. Alteração do caput da Instrução Normativa MAPA n. 51, de 18 de setembro de 2002. Diário Oficial da União, Brasília, 29 dez 2011.

Bueno, V. F. F.; Mesquita, A. J.; Oliveira, A. N.; Nicolau, E. S. and Neves, R. B. S. 2008. Contagem bacteriana total do leite: relação com a composição centesimal e o período do ano no Estado de Goiás. Revista Brasileira de Ciências Veterinárias 15:40-44.

Chavez, M.; Negri, L. M.; Taverna, M. A. and Cuatrín, A. 2004. Bovine milk composition parameters affecting the ethanol stability. Journal Dairy Research 71:201-206.

Donatele, D. M.; Vieira, L. F. P. and Folly, M. M. 2003. Relação do teste de Alizarol a $72 \%$ (v/v) em leite in natura de vaca com acidez e contagem de células somáticas: análise microbiológica. Higiene Alimentar 17:95-100.

Fagnani, R.; Beloti, V. and Battaglini, A. P. P. 2014. Acid-base balance of dairy cows and its relationship with alcoholic stability and mineral composition of milk. Pesquisa Veterinária Brasileira 34:398-402.

Fagnani, R.; Battaglini, A. P. P.; Beloti, V. and Araújo, J. P. A. 2016. Estabilidade do leite ao álcool ainda pode ser um indicador confiável? Ciência Animal Brasileira 17:386-394.

Farahnik, S. A. 1982. Quality control program recommendation for uht processing and aseptic packing of milk and milk byproducts. Dairy Food Sanitation 2:454-457.

Fischer, V.; Ribeiro, M. E. R.; Zanela, M. B.; Marques, L. T.; Abreu, A. S.; Machado, S. C.; Fruscalso, V.; Barbosa, R. S. and Stumpf, M. T. 2012. Leite instável não ácido: um problema solucionável? Revista Brasileira de Saúde e Produção Animal 13:838-849.
Fonseca, L. F. L. and Santos, M. V. 2000. Qualidade do leite e controle de mastite. Lemos Editorial, São Paulo.

Fonteh, F. A.; Grandison, A. S.; Lewis, M. J. and Niba, A. T. 2005. The keeping quality of LPS-activated milk in the western highlands of Cameroon. Livestock Research Rural Development 17:114.

Gabbi, A. M.; McManus, C. M.; Silva, B. A. V.; Marques, L. T. C.; Zanela, M. B.; Stumpf, M. P. and Fischer, V. A. 2013. Typology and physical-chemical characterization of bovine milk produced with different productions strategies. Agricultural Systems 121:130-134.

Gabbi, A. M.; McManus, C. M.; Zanela, M. B.; Stumpf, M. T.; Barbosa, R. S.; Fruscalso, V.; Thaler Neto, A.; Schmidt, F. A. and Fischer, V. 2016. Milk traits of lactating cows submitted to feed restriction. Tropical Animal Health Production 48:37-43.

Gaucheron, F. 2005. The minerals of milk - review. Reproduction Nutrition Development 45:473-483.

Horne, D. S. and Muir, D. D. 1990. Alcohol and heat stability of milk protein. Journal Dairy Research 46:433-439.

Horne, D. S. 2015. Ethanol stability and milk composition. In: Advanced dairy chemistry. Volume 1B: Proteins: Applied aspects. 4th ed. McSweeney, P. L. H. and O'Mahony, J. A., eds. Springer, Cork.

Kassa, F.; Yilma, Z.; Assefa, G.; Bekele, T.; Gojam, Y.; Nebiyu, R. and Kassa, B. 2013. Evaluation of Lactoperoxidase system as raw milk preservative at different storage temperature conditions in the central highlands of Ethiopia. Livestock Research for Rural Development 25, Article \#68.

Kolling, G. K. 2012. Influência da mastite na qualidade do leite e leite instável não ácido em diferentes quartos mamários. Dissertação (M.Sc.). Universidade Federal do Rio Grande do Sul. Porto Alegre, RS, Brasil.

Lewis, M. J. and Deeth, H. C. 2009. Heat treatment of milk. p.168-204. In: Milk processing and quality management. Tamine, A. Y., ed. Wiley-Blackwell, Chichester, UK

Lewis, M. J. 2011. The measurement and significance of ionic calcium in milk a review. International Journal Dairy Technology 64:1-13.

Lin, M. J.; Li, Y. C.; Lin, Y. C. and Chen, K. J. 2009. Study on cow's milk quality in the eastern Taiwan during hot season. Journal of Chinese Society Animal Science 38:87-95.

Marques, L. T.; Zanela, M. B.; Ribeiro, M. E. R.; Stumpf, J. R. W. and Fischer, V. 2007. Ocorrência do leite instável ao álcool 76\% e não ácido (LINA) e efeito sobre os aspectos físico-químicos do leite. Revista Brasileira de Agrociência 13:91-97.

Marques, L. T.; Fischer, V.; Zanela, M. B.; Ribeiro, M. E. R.; Stumpf, J. R. W. and Mazke, N. 2010a. Fornecimento de suplementos com diferentes níveis de energia e proteína para vacas Jersey e seus efeitos sobre a instabilidade do leite. Revista Brasileira de Zootecnia 39:2724-2730

Marques, L. T.; Fischer, V., Zanela, M. B.; Stumpf Jr., W.; Ribeiro, M. E. R.; Barros, L. E. V.; Rodrigues, C. M. and Peters, M. D. 2010b. Suplementação de vacas holandesas em estádio avançado de lactação. Ciência Rural 40:1392-1398.

Marques, L. T.; Fischer, V.; Zanela, M. B.; Ribeiro, M. E. R.; Stumpf Junior, W. and Rodrigues, C. M. 2011. Milk yield, milk composition and biochemical blood profile of lactating cows supplemented with anionic salt. Revista Brasileira de Zootecnia 40:1088-1094.

Molina, L. H.; González, R.; Brito, C.; Carrillo, B. and Pinto, M. 2001. Correlacion entre la termoestabilidad y prueba de alcohol de la leche a nivel de un centro de acopio lechero. Archivo de Medicina Veterinária 33:233-240.

Negri, L. M.; Chavez, M.; Costabel, L. and Taverna, M. 2011. Composición de leche de tanque, silo y derivados, relaciones con la estabilidad térmica y variables de manejo. p.6-9. In: Conferencia Internacional sobre Leche Instable, Colonia del Sacramento. INIA, Colonia del Sacramento. 
Negri, L.; Chavez, M.; Taverna, M.; Roberts, L. and Speranza, J. 2001. Fatores que afectan la estabilidad térmica y la prueba de alcohol en leche cruda de calidad higiénica adecuada: informe técnico final del proyecto. INTA EEA/INTI CITIL, Rafaela. 27p.

Nian, Y.; Chen, B.; Aikman, P.; Grandison, A. and Lewis, M. 2012. Naturally occurring variations in milk $\mathrm{pH}$ and ionic calcium and their effects on some properties and processing characteristics of milk. International Journal of Dairy Technology 65:490-497.

Oliveira, C. A. F.; Lopes, L. C.; Franco, R. C. and Corassin, C. H. 2011. Composição e características físico-químicas do leite instável não ácido recebido em laticínio do Estado de São Paulo, Brasil. Revista Brasileira de Saúde e Produção Animal 12:508-515.

Oliveira, C. A. F.; Lopes, L. C.; Rosim, R. E.; Fernandes, A. M. and Corassin, C. H. 2013. Composition, somatic cell count and casein fractions of ethanol unstable milks. Acta Scientiarum 35:153-156.

Philippe, M.; Gaucheron, F.; Graet, Y. L.; Michel, F. and Garem, A. 2003. Physicochemical characterization of calcium-supplemented skim milk. Le Lait 83:45-59.

Rathnayake, R.; Mangalika, U.; Adikari, A. and Nayananjalie, W. 2016. Changes in compositional and keeping quality parameters of cow milk on ethanol stability. International Journal of Livestock Research 6:83-89.

Silva, L. C. C.; Beloti, V.; Tamanini, R.; Yamada, A. K.; Giombelli, C. J. and Silva, M. R. 2012. Estabilidade térmica da caseína e estabilidade ao álcool 68, 72, 75 e 78\%, em leite bovino. Revista do instituto de laticínios Cândido Tostes 67:55-66.
Singh, H. 2004. Heat Ssability of milk. International Journal Dairy Technology 57:111-119.

Smyth, E.; Clegg, R. A. and Holt, C. 2004. A biological perspective on the structure and function of caseins and casein micelles. International Journal Dairy Technology 57:121-126.

Stelwagen, K.; Hopstert, H.; Van Der Werf, J. T. N. and Blokhuist, H. J. 2000. Short communication: effects of isolation stress on mammary tight junctions in lactating dairy cows. Journal of Dairy Science 83:48-51.

Stumpf, M. T.; Fischer, V.; McManus, C. M.; Kolling, G. J.; Zanela, M. B.; Santos, C. S.; Abreu, A. S. and Montagner, P. 2013. Severe feed restriction increases permeability of mammary gland cell tight junctions and reduces ethanol stability of milk. Animal 7:1137-1142.

Tsiouplas, A.; Lewis, M. J. and Grandison, A. S. 2007. Effect of minerals on casein micelle stability of cows' milk. Journal Dairy Research 74:167-173.

Werncke, D.; Gabbi, A. M.; Abreu, A. S.; Felipus, N. C.; Machado, N. L.; Cardoso, L. L.; Schmid, F. A.; Alessio, D. R. M.; Fischer, V. and Thaler Neto, A. 2016. Qualidade do leite e perfil das propriedades leiteiras no sul de Santa Catarina: abordagem multivariada. Arquivo Brasileiro de Medicina Veterinária e Zootecnia 68:506-516.

Zanela, M. B.; Fischer, V.; Ribeiro, M. E. R.; Stumpf, J. R. W.; Zanela, C.; Marques, L. T. and Martins, P. R. G. 2006. Qualidade do leite em sistemas de produção na região Sul do Rio Grande do Sul. Pesquisa Agropecuária Brasileira 41:153-159. 